\title{
Travellers' self-protections against health risks: An application of the full protection motivation theory
}

\author{
Jie Wang a Bingjie Liu-Lastres ${ }^{b}$ Brent W. Ritchie a Deborah J. Mills ${ }^{\mathrm{c}}$ \\ a \\ School of Business, The University of Queensland, Brisbane, Queensland 4072, \\ $\mathrm{b}$ \\ Australia \\ School of Health and Human Science, Indiana University-Purdue University, \\ Indianapolis, IN 46202, USA \\ $\mathrm{c}$ \\ Travel Medicine Alliance, Brisbane, Australia
}

\section{ABSTRACT}

Ensuring travellers' health and well-being is an important issue in tourism management and public health. By applying and testing the Protection Motivation Theory (PMT), this study serves as one of the early attempts in tourism to explore travellers' self-protective behavior against health risks. This study conducted semi-structured interviews and an online survey. Consistent with the PMT, this study found that both threat and coping appraisals can enhance travellers' protection motivations, which in turn affect their actual behaviors. Intentions play a mediation role between appraisals and actual behavior. Notably, maladaptive perception was adapted to fit tourism and was found negatively associated with the coping appraisal. This study also provides implications on how to encourage travellers to protect themselves against health risks.

\section{KEYWORDS}

Travel; health risk; Protection Motivation Theory; coping appraisal; threat appraisal; maladaptive perceptions

This is the author's manuscript of the work published in final edited form as:

Wang, J., Liu-Lastres, B., Ritchie, B. W., \& Mills, D. J. (2019). Travellers' self-protections against health risks: An application of the full Protection Motivation Theory. Annals of Tourism Research, 78, 102743. https://doi.org/10.1016/j.annals.2019.102743 
30 International tourist arrivals have increased from 25 million globally in 1950 to 1,235 million 31 in 2016 (UNWTO, 2017). The continued growth in international tourism, however, has caused 32 global health consequences (Richter, 2003). These might arise from the effects of sudden and 33 significant changes in altitude, humidity, microbes, and temperature on individual travellers 34 (World Health Organization [WHO], 2018). Conservative estimates show that 30 to 50\% of travellers become ill or are injured during their trip indicating that raising awareness of these problems is urgent (Briggs \& Habib, 2004). At destinations, serious health risks may arise where accommodation is of poor quality, hygiene and sanitation are inadequate, medical services are not well-developed, and clean water is unavailable (WHO, 2017). Additionally, constant outbreaks of health-related crises at destinations can threaten the health and well-being of tourists. For instance, recent events such as the Ebola (Novelli, Burgess, Jones, \& Ritchie, 2018) and other infectious diseases (Rack et al., 2005) have negatively impacted both travellers' health and the tourism industry within the destination. Spill-over effects may occur on some occasions, where not only the destination, but also the surrounding region may suffer from the negative impacts generated by health-related crises (Novelli et al., 2018).

\subsection{Research problem and research aim}

Although both what the tourism industry supplies and what tourists demand at destinations of certain countries may be affected by health-related crises, operators are expected to take some responsibility for protecting travellers' health and safety (Atherton \& Atherton, 1998). Selfservingly, tourism practitioners tend to keep the "bad news" away from the public as it may negatively impact holiday sales (Wilks, Stephen, \& Moore, 2013). Nevertheless, the increasing recognition given to tourists' health and safety issues motivates operators and tourism practitioners to realize that good health and safety practices can benefits their turnover, prevent litigations, and produce customer satisfaction and loyalty (Wilks et al., 2013). However, although how the tourism industry responds to and manages health-related issues is well covered (e.g., Frisby, 2003; Henderson, 2004; Liu, Kim, \& Pennington-Gray, 2015), the demand side related to the risk and health of individuals when they travel is less well addressed (Chien, Sharifpour, Ritchie, \& Watson, 2016; Novelli et al., 2018). 
independence has increased since the previous decade (Caruana, Crane, \& Fitchett, 2008;

61 Ourahmoune, 2016; Tsaur, Yen, \& Chen, 2010). Similar to other individuals, rational tourists tend to be risk-averse and avoid dangerous situations. Once their maximum tolerance level to risk is reached, travellers may change their original travel plans so they include risk reduction and thus decrease their uncertainty and perceived risk (Mitchell, Davies, \& Moutinho, 1999). This approach can become manifest as information, procedures, and actions (Lo, Cheung, \& Law, 2011). Although some tourism studies have been carried out to examine travellers' health risk perceptions (Jonas, Mansfeld, Paz, \& Potasman, 2011), few explore how individuals adopt risk reduction (Lo et al., 2011). Similarly, very few studies examine how travellers behave to protect health when they travel (Chien et al., 2016).

Regarding public health, protection motivation theory (PMT) is useful to explain how and why people behave to protect their health (Floyd, Prentice-Dunn, \& Rogers, 2000). While PMT has been applied to tourism and travel (e.g., Law, 2006; Slevitch \& Sharma, 2008), it occupies only a minor part of health science because these researchers only used part of it. Because tourism studies are interdisciplinary, developing them requires two outcomes: first, to show what the disciplines involved achieve; and second, to combine the tools used in each discipline to provide a method that enables tourism to be studied many-sidedly (Darbellay \& Stock, 2012). Thus, the purpose of this study is more than simply applying the PMT model to understand travellers' health protective behavior. Using the PMT model, this study aims to comprehensively understand individuals' health behavior during travel. It is expected that the findings of this study could expand the present understanding of travellers' individual health protective behaviors and contribute to both the tourism and the public health literature.

\subsection{Research context}

83 Australia is important in the global tourism market producing, in 2016, 8.3 million short-term international departures with 3 million (36\%) of them being to Asia. Despite this popularity, many Australian travellers are not aware of the potential health risks in Asian destinations and what they should do to protect themselves. This may be because many of the fatal diseases in Asian destinations do not affect Australia. Rabies is a prime example, a viral disease that affects humans and other mammals. Both bites and licks by an infected animal (dog, cat, monkey, bat,

89 etc.) can lead to rabies. Over 59,000 people die of rabies worldwide each year, with $59.6 \%$ of 90 these rabies deaths occurring in Asia (Hampson et al., 2015). While countries like Indonesia, 91 Thailand and Vietnam may be top tourism destinations for Australian travellers, they are 
92 significantly at risk suffering rabies there (Piyaphanee et al., 2012). Furthermore, tourists 93 cannot rely on being adequately treated for rabies if they are bitten overseas (Mills, Lau, \& 94 Weinstein, 2011). Consequently, rabies has become a significant health issue for Australian 95 travellers (Wilson \& Rohde, 2015).

96 Despite being a fatal disease, death from rabies is preventable if treated before symptoms 97 develop. Such risk reduction information and how to prevent it can be obtained from health 98 professionals prior to leaving, although few travellers inexplicably choose to do so (Heywood, 99 Watkins, Iamsirithaworn, Nilvarangkul, \& MacIntyre, 2012). As well, avoiding wild animal 100 contacts has been listed by officials as one of the major risk reduction strategies against rabies 101 (Australian Department of Foreign Affairs and Trade, 2018) (See Graph 1).

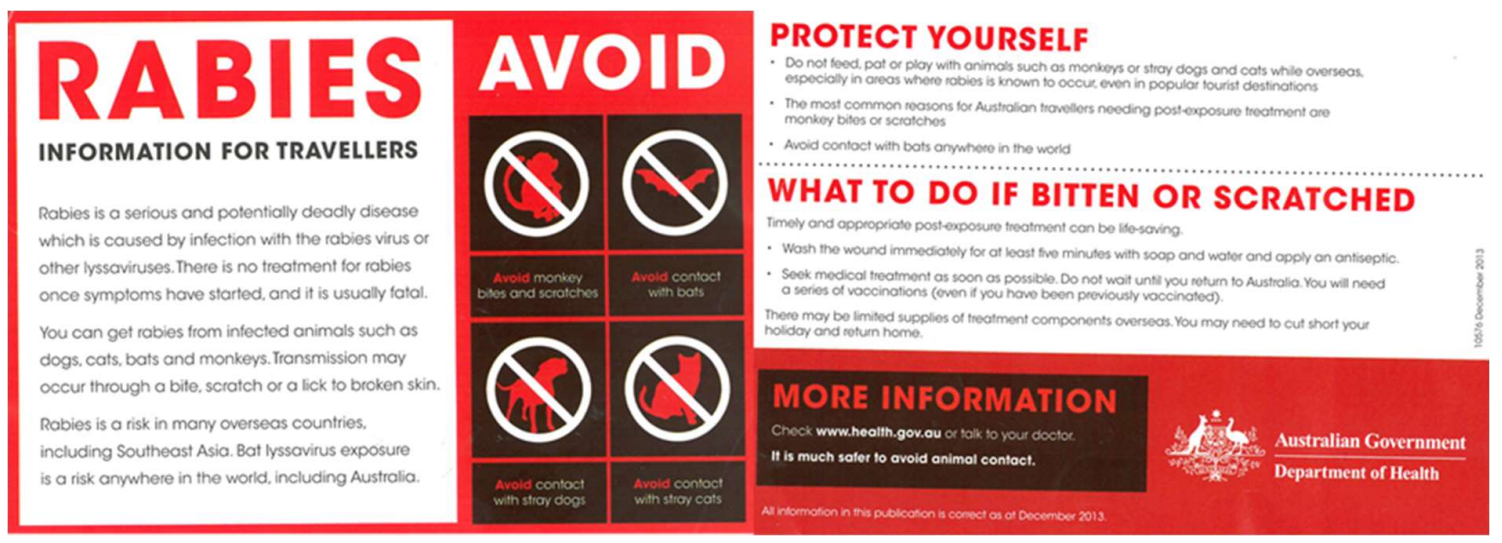

104 Because of the threat of being severely unwell and that tourists can benefit if they protect their 105 health, the risk of rabies in Southeast Asia is especially important to Australians. This provides 106 an ideal research topic. Particularly, this study aims to explore the application of PMT to 107 understand how Australian travellers protect themselves against rabies to ensure they stay 108 healthy when traveling to Southeast Asia.

\section{THEORETICAL FOUNDATION}

\section{$110 \quad 2.1$ Protection Motivation Theory}

111 As an important topic in public health, a wide variety of models have been developed and 112 applied to investigate individuals' health behavior; these models are the health belief model, 113 social cognition theory, and the theory of planned behavior (Conner \& Norman, 2005). Among 
114 them, protection motivation theory (PMT) appears to be one of the most comprehensive models

115 used empirically (Floyd et al., 2000). In being adapted from expectancy-value theory and the 116 components of reward and self-efficacy, PMT provides the means of explaining why people 117 engage in health protective behaviors. Under the influence of environmental and intrapersonal 118 factors, people go through one of the two mediating processes (i.e., threat-appraisal and coping119 appraisal), which normally result in one of the two coping modes (i.e., adaptive coping and 120 maladaptive coping) (Milne, Sheeran, \& Orbell, 2000). Adaptive coping normally leads to 121 people's engagement and/or continual engagement in corresponding health protective 122 behaviors, while maladaptive coping usually causes individuals' decisions to inhibit the 123 corresponding health protective behavior (Floyd et al., 2000).

124 When it comes to the relationships among the constructs, the results of two early meta-analyses 125 of PMT studies (Floyd et al., 2000; Milne et al., 2000) report that an increase in severity, 126 susceptibility, response and self-efficacy significantly affect coping appraisal, which result in 127 stronger probability of adapting responses. Meanwhile, Floyd et al. (2000) noted that 128 decreasing maladaptive response rewards and adaptive response costs would generally increase 129 adaptive responses. Additionally, Milne et al., (2000) notice that variables in coping appraisal 130 tend to have stronger associations with the outcome variables (i.e., intentions and actual 131 behaviors) than those outlined in threat appraisal. Additionally, variables in threat appraisal 132 (e.g., perceived severity and vulnerability) are poorly linked to people's motivations to engage 133 in health protection (Milne et al., 2000). The findings of 10 years of research also support the 134 validity of the abovementioned relationships (e.g., Bockarjova \& Steg, 2014; Pechmann, Zhao, 135 Goldberg, \& Reibling, 2003; Plotnikoff \& Trinh, 2010; Rainear \& Christensen, 2017). 136 However, most research using PMT pays attention only to adaptive coping rather than the 137 whole model, and ignores the effect of maladaptive responses (Conner \& Norman, 1996; 138 Marett, McNab, \& Harris, 2011).

139 Undeniably, PMT remains one of the most widely used models in public health to examine 140 individual health behaviors (Conner \& Norman, 2005), for example, being used to test cancer 141 prevention, healthy lifestyle, and pro-environmental behavior (Floyd et al., 2000; Milne et al., 142 2000). While these authors support to applying PMT, rabies, as an important health challenge, 143 has not been featured within research based on PMT. 


\subsection{PMT in tourism}

145 While the PMT model is applied to tourism and travel (e.g., Law, 2006; Slevitch \& Sharma, 146 2008; Sönmez \& Graefe, 1998), it remains underexplored among the PMT literature. Table 1

147 summarises the examples of such studies. A closer examination of this body of literature has

148 revealed some notable perspectives.

149 Table 1: Tourism and travel articles using PMT

\begin{tabular}{|c|c|c|c|c|c|}
\hline & Author & Title & $\begin{array}{l}\text { Theoretical } \\
\text { Models } \\
\end{array}$ & Major Constructs & Major Findings \\
\hline 1 & $\begin{array}{l}\text { (Sönmez \& } \\
\text { Graefe, 1998) }\end{array}$ & $\begin{array}{l}\text { Determining Future } \\
\text { Travel Behavior from } \\
\text { Past Travel } \\
\text { Experience and } \\
\text { Perceptions of Risk } \\
\text { and Safety }\end{array}$ & $\begin{array}{l}\text { Information } \\
\text { integration } \\
\text { theory + PMT }\end{array}$ & $\begin{array}{l}\text { IV: Risk } \\
\text { (single measurement on } \\
\text { perceived vulnerability) } \\
\text { DV: avoidance of } \\
\text { visiting certain regions }\end{array}$ & $\begin{array}{l}\text { Perceived risks were } \\
\text { stronger predictors of } \\
\text { avoiding regions than of } \\
\text { planning to visit them. } \\
\text { PMT can be used to explain } \\
\text { the participants' behavioral } \\
\text { intentions. }\end{array}$ \\
\hline 2 & (Law, 2006) & $\begin{array}{l}\text { The Perceived Impact } \\
\text { of Risks on Travel } \\
\text { Decisions }\end{array}$ & PMT & $\begin{array}{l}\text { IV: Risk } \\
\text { (single measurement on } \\
\text { perceived vulnerability) } \\
\text { IV: Efficacy of official } \\
\text { media } \\
\text { DV: Travel Intentions }\end{array}$ & $\begin{array}{l}\text { Perceived risk affected } \\
\text { individuals' visiting } \\
\text { intentions }\end{array}$ \\
\hline 3 & $\begin{array}{l}\text { (Slevitch \& } \\
\text { Sharma, 2008) }\end{array}$ & $\begin{array}{l}\text { Management of } \\
\text { Perceived Risk in the } \\
\text { Context of } \\
\text { Destination Choice }\end{array}$ & PMT & $\begin{array}{l}\text { IV: Risk } \\
\text { (single measurement on } \\
\text { perceived severity) } \\
\text { DV: Travel intentions } \\
\text { and Behavioral } \\
\text { Intentions }\end{array}$ & $\begin{array}{l}\text { Perceived risks were } \\
\text { decreased by information } \\
\text { quality but various patterns } \\
\text { were identified for different } \\
\text { types of perceived risk. } \\
\text { Travelers were willing to } \\
\text { pay extra for products and } \\
\text { services if more safety and } \\
\text { security are provided. }\end{array}$ \\
\hline 4 & $\begin{array}{l}\text { (Qi, Gibson, \& } \\
\text { Zhang, 2009) }\end{array}$ & $\begin{array}{l}\text { Perceptions of risk } \\
\text { and travel intentions: } \\
\text { The case of China and } \\
\text { the Beijing Olympic } \\
\text { Games }\end{array}$ & PMT & $\begin{array}{l}\text { IV: Risk } \\
\text { (single measurement on } \\
\text { perceived severity) } \\
\text { DV: Intentions to visit } \\
\text { Beijing to attend the } \\
\text { Olympic Games }\end{array}$ & $\begin{array}{l}\text { Risk Perception affects } \\
\text { individuals' visiting } \\
\text { intentions } \\
\text { Efficacy beliefs varied by } \\
\text { tourists from different } \\
\text { regions }\end{array}$ \\
\hline 5 & $\begin{array}{l}\text { (Schroeder, } \\
\text { Pennington- } \\
\text { Gray, } \\
\text { Kaplanidou, \& } \\
\text { Zhan, 2013) }\end{array}$ & $\begin{array}{l}\text { Destination risk } \\
\text { perceptions among } \\
\text { U.S. residents for } \\
\text { London as the host } \\
\text { city of the } 2012 \\
\text { Summer Olympic } \\
\text { Games }\end{array}$ & $\begin{array}{l}\text { Information } \\
\text { integration } \\
\text { theory + PMT }\end{array}$ & $\begin{array}{l}\text { IV: Risk } \\
\text { (single measurement on } \\
\text { perceived vulnerability) } \\
\text { DV: Visiting Intentions }\end{array}$ & $\begin{array}{l}\text { Three destination risk } \\
\text { perception items were the } \\
\text { drivers of the intention to } \\
\text { travel to a host city. }\end{array}$ \\
\hline 6 & $\begin{array}{l}\text { (Horng, Hu, } \\
\text { Teng, \& Lin, } \\
\text { 2014) }\end{array}$ & $\begin{array}{l}\text { Energy Saving and } \\
\text { Carbon Reduction } \\
\text { (ESCR) Behaviors in } \\
\text { Tourism - A } \\
\text { Perception Study of } \\
\text { Asian Visitors from a } \\
\text { Protection Motivation } \\
\text { Theory Perspective }\end{array}$ & PMT & $\begin{array}{l}\text { IV: PMT constructs } \\
\text { (Risk was measured in } \\
\text { terms of the } \\
\text { vulnerability to } \\
\text { environmental risk and } \\
\text { the severity of } \\
\text { environmental risk } \\
\text { using multiple items) } \\
\text { DV: ESCR behavior }\end{array}$ & $\begin{array}{l}\text { Obvious differences } \\
\text { between tourists' ESCR } \\
\text { behavior intention and } \\
\text { actual behavior are found }\end{array}$ \\
\hline
\end{tabular}




\begin{tabular}{|c|c|c|c|c|c|}
\hline 7 & $\begin{array}{l}\text { (Defranco \& } \\
\text { Morosan, } \\
\text { 2017) }\end{array}$ & $\begin{array}{l}\text { Coping with the risk } \\
\text { of internet } \\
\text { connectivity in hotels: } \\
\text { Perspectives from } \\
\text { American consumers } \\
\text { traveling } \\
\text { internationally }\end{array}$ & $\begin{array}{l}\text { Social } \\
\text { Cognitive } \\
\text { Theory + PMT }\end{array}$ & $\begin{array}{l}\text { IV: Benefit } \\
\text { IV: Risk } \\
\text { (Measured in terms of } \\
\text { perceived vulnerability } \\
\text { and perceived severity } \\
\text { using multiple items) } \\
\text { DV: Coping Intentions }\end{array}$ & $\begin{array}{l}\text { Both benefit and risk were } \\
\text { relatively equal magnitude } \\
\text { predictors of coping } \\
\text { intentions, while benefit had } \\
\text { a slightly stronger effect on } \\
\text { coping intentions than risk. }\end{array}$ \\
\hline 8 & $\begin{array}{l}\text { (Wang, Lin, } \\
\text { Lu, \& Lee, } \\
\text { 2018) }\end{array}$ & $\begin{array}{l}\text { When destination } \\
\text { attractiveness shifts in } \\
\text { response to climate } \\
\text { change: tourists' } \\
\text { adaptation intention in } \\
\text { Taiwan's Kenting } \\
\text { National Park }\end{array}$ & PMT & $\begin{array}{l}\text { IV: climate change } \\
\text { related threat appraisal } \\
\text { (Risk was measured } \\
\text { using multiple items in } \\
\text { terms of vulnerability } \\
\text { and severity) } \\
\text { IV: Coping Appraisal } \\
\text { DV: Tourists' Adaption } \\
\text { Intentions }\end{array}$ & $\begin{array}{l}\text { The results support the } \\
\text { relationships between threat } \\
\text { appraisal and adaptation } \\
\text { intention, and coping } \\
\text { appraisal and adaptation } \\
\text { intention }\end{array}$ \\
\hline 9 & $\begin{array}{l}\text { (Lu \& Wei, } \\
\text { 2018) }\end{array}$ & $\begin{array}{l}\text { Public's perceived } \\
\text { overcrowding risk and } \\
\text { their adoption of } \\
\text { precautionary actions: } \\
\text { a study of holiday } \\
\text { travel in China }\end{array}$ & $\begin{array}{l}\text { protective } \\
\text { action decision } \\
\text { model and PMT }\end{array}$ & $\begin{array}{l}\text { IV: Risk was measured } \\
\text { in terms of perceived } \\
\text { severity using multiple } \\
\text { items. } \\
\text { DV: Behavioral } \\
\text { intentions }\end{array}$ & $\begin{array}{l}\text { Efficacy-related attributes } \\
\text { of precautionary actions } \\
\text { were positively correlated } \\
\text { with the intention to take } \\
\text { precautionary measures. } \\
\text { Risk perception also } \\
\text { significantly influenced the } \\
\text { adoption intention }\end{array}$ \\
\hline 10 & $\begin{array}{l}\text { (Fisher, } \\
\text { Almanza, } \\
\text { Behnke, } \\
\text { Nelson, \& } \\
\text { Neal, 2018) }\end{array}$ & $\begin{array}{l}\text { Norovirus on cruise } \\
\text { ships: Motivation for } \\
\text { handwashing? }\end{array}$ & PMT & $\begin{array}{l}\text { IV: Threat Appraisal } \\
\text { (Risk was measured } \\
\text { using multiple items in } \\
\text { terms of vulnerability } \\
\text { and severity) } \\
\text { IV: Coping Appraisal } \\
\text { DV: Behavioral } \\
\text { Intentions }\end{array}$ & $\begin{array}{l}\text { Threat appraisal not related } \\
\text { Coping Appraisal related }\end{array}$ \\
\hline
\end{tabular}

150 First, one of the most notable focuses shared by travel risk studies and PMT deals with tourists'

151 risk perception. Although risk perception varies in PMT and other health and psychological

152 studies (Maddux \& Rogers, 1983; Rogers, 1975), it basically involves two dimensions:

153 perceived severity and perceived vulnerability (Conner \& Norman, 2005). Early tourism risk

154 research, however, tended to focus only on one aspect. Some focus only on perceived

155 vulnerability, which considers the likelihood of the occurrence of a risky event (e.g., Schroeder,

156 Pennington-Gray, Donohoe, \& Kiousis, 2013; Sönmez \& Graefe, 1998), while others measure

157 travellers' perceived severity only, which deals with risk's severe consequence (Law, 2006).

158 The inconsistency in travel risk studies has nonetheless been superficial and thus struggled to

159 put theory into practice (Yang \& Nair, 2014).

160 Second, some travel risk research has recently added two variables to PMT: self-efficacy (e.g.,

161 Law, 2006) and benefits (Defranco \& Morosan, 2017). Some tests the relationships among the

162 PMT constructs (e.g., Fisher et al., 2018; Horng et al., 2014), although their findings appear

163 inconsistent with original PMT assumptions. For example, while Fishers et al. (2018) find that

164 only coping appraisal relates to cruise passengers' intention of behaving to self-protect during 
165 travel, threat-appraisal seems to be irrelevant. These inconsistencies call to be further validated 166 regarding applying PMT to tourism and travel.

167 Third, most tourism risk studies using PMT make people's travel intentions as the outcome 168 variable (e.g., Law, 2006; Slevitch \& Sharma, 2008; Sönmez \& Graefe, 1998). It is not until 169 recently that tourism studies have focused on travellers' intentions to undertake preventive 170 behaviors (e.g., Fisher et al., 2018; Lu \& Wei, 2018; Wang et al., 2018). Although behavioral 171 intentions can indicate one's actual behaviors, it may not always be accurate as expected 172 (Stacks \& Michaelson, 2010). Also, the PMT model suggests a transition between intention 173 and behavior. As such, measuring travellers' behavior should be important to travel risk 174 research.

175 Lastly, according to PMT, maladaptive perception is an important construct that affects 176 people's personal health behaviors. Maladaptive coping response refers to individuals' attempt 177 to reduce their level of fear without engaging in actions to reduce the risk and/or danger 178 (Rippetoe \& Rogers, 1987). Maladaptive responses have been found as one of the major 179 reasons why the most at-risk group would not be convinced to appropriately reduce risk 180 (Tanner, Hunt, \& Eppright, 1991). Despite its influence, we believe that no studies in tourism 181 have included this construct and tested the effects. This is somehow consistent with the major 182 trend of the PMT studies (see Floyd et al., 2000; Milne et al., 2000), but should be corrected 183 with an attempt to develop a comprehensive but innovative approach.

\section{$184 \quad 2.3$ The conceptual model}

185 This study aims to fill these three knowledge gaps. The first is to focus on how individual 186 tourists behave to prevent the risk to their health, particularly pertaining to Australian travellers' 187 health and the risk of rabies infections in popular Southeast Asian destinations. Second, instead 188 of measuring only how Australian travellers intend to behave, this study considers how this 189 behavior manifests itself as seen in how they act on their intentions. Third, this study 190 contributes to the literature by testing a full PMT model in tourism and travel research. The 191 results not only expand PMT research, but also importantly shows how tourism risk studies 192 contribute when they are modified and revised accordingly. A conceptual model was developed 193 based on the PMT and the research context of the study (See Figure 1). The threat appraisal 194 represents the differences between perceived rewards and perceived threat, while the coping 
197 Figure 1: A conceptual model of key factors influencing protective behaviours with hypotheses

198
Knowledge gap

- No tourism studies have
tested the full PMT
model
- Most PMT studies only
test individuals'
behavioural intentions,
while very few of them
have examined their
actual behaviors
- Maladaptive perception,
as an important PMT
construct, has not been
tested in the tourism
and travel literature

Cognitive Mediating Processes

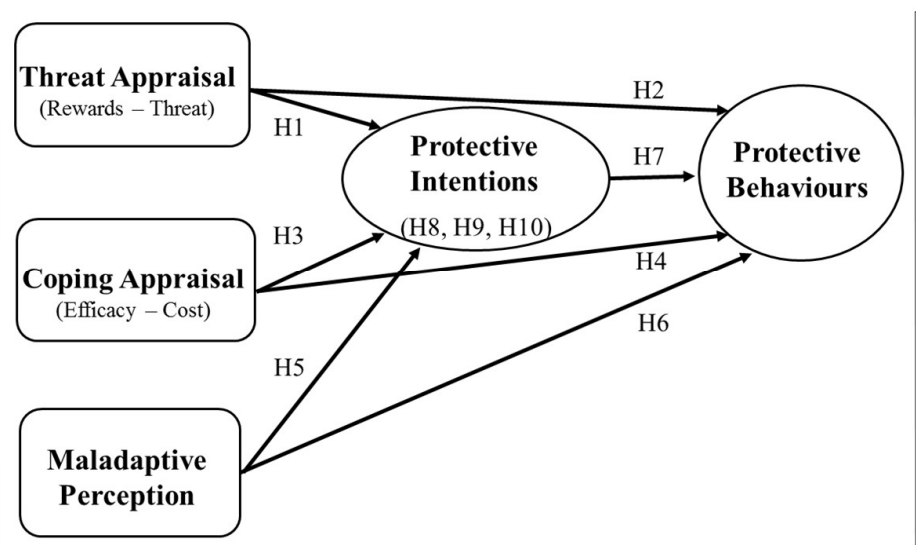

Source: Adapted from Rippetoe and Rogers (1987), and Yan et al. (2014)
Contribution

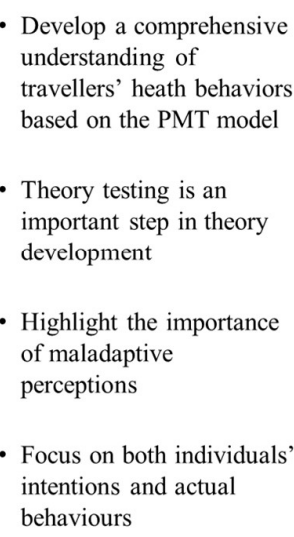

- Develop a comprehensive understanding of travellers' heath behaviors based on the PMT model

Theory testing is an important step in theory development

- Highlight the importance of maladaptive perceptions

- Focus on both individuals intentions and actual behaviours

\section{The hypotheses include:}

Hypothesis 1: Australian travellers' intentions of engaging in protective behaviors are positively associated with the threat appraisal process.

Hypothesis 2: Australian travellers' engagement in protective behaviors are positively associated with the threat appraisal process.

Hypothesis 3: Australian travellers' intentions of engaging in protective behaviors are positively associated with the coping appraisal process.

Hypothesis 4: Australian travellers' engagement in protective behaviors are positively associated with the coping appraisal process.

Hypothesis 5: Australian travellers' intentions of engaging in protective behaviors are negatively associated with maladaptive perception.

Hypothesis 6: Australian travellers' engagement in protective behaviors are negatively associated with maladaptive perception.

Hypothesis 7: Australian travellers' intentions of engagement in protective behaviors are positively associated with their actual behaviors.

Hypothesis 8: Australian travellers' intentions to protect themselves mediate the relationship between the threat appraisals and their actual behaviors.

Hypothesis 9: Australian travellers' intentions to protect themselves mediate the relationship between the coping appraisals and their actual behaviors.

Hypothesis 10: Australian travellers' intentions to protect themselves mediate the relationship between maladaptive perception and their actual behaviors. 


\subsection{Data collection}

222 This study was conducted over two phases. First, semi-structured interviews were undertaken 223 with sixteen Australian travellers from 5 to 29 June 2017 to understand their attitudes and 224 perceptions toward travel health risks, actual or planned behaviors of rabies risk-reduction 225 strategies for their past or intended trips to Southeast Asia. Second, based on the interview 226 results and the literature, a questionnaire was developed, and an online survey was conducted 227 in November 2017. The participants were recruited through an online panel provided by a 228 market research company.

229 In the first phase, purposive sampling was used to recruit interview participants. A pilot test 230 was performed before the interview to test the feasibility and relevance of the questions. An 231 interview guide was developed to ascertain tourists' attitudes and perceptions, including their 232 travel health perceptions of destinations in Southeast Asia, self-protective behaviors and related 233 benefits and disadvantages, and travellers' knowledge of rabies. After the interview guide was 234 developed, two academic experts and one travel medicine practitioner reviewed the pilot-test 235 results. The interview was then conducted in English using either by telephone or face-to-face, 236 depending on participants' preferences, the 16 of which involved Australian tourists who had 237 visited Indonesia, Thailand, and Vietnam in the preceding three years or intend to travel there 238 in the next three. Including intended participants was to understand people's attitudes, and what 239 motivates them to protect themselves. To maintain confidentiality, the participants were 240 assigned codes (see Table 2 for their profiles). All interviews were transcribed, and notes were 241 taken during and immediately after each interview.

242 Table 2: Profile of interview participants (Nationality: Australia; age >18)

\begin{tabular}{|c|c|c|c|c|c|c|}
\hline \multirow[t]{2}{*}{ Code } & \multirow[t]{2}{*}{ Age } & \multirow[t]{2}{*}{ Gender } & \multicolumn{2}{|c|}{ Past travel history } & \multicolumn{2}{|c|}{ Travel Intention } \\
\hline & & & Time & Destination & Time & Destination \\
\hline P1 & 45 & Male & 2011 & $\begin{array}{l}\text { Vietnam } \\
\text { Thailand }\end{array}$ & Over the next 3 years & Vietnam \\
\hline $\mathrm{P} 2$ & 65 & Female & - & - & Over the next 3 years & Vietnam \\
\hline P3 & 38 & Male & $\begin{array}{l}2014 \\
2015\end{array}$ & $\begin{array}{l}\text { Thailand } \\
\text { Indonesia }\end{array}$ & - & - \\
\hline $\mathrm{P} 4$ & 31 & Male & - & - & Over the next 3 years & Thailand \\
\hline P5 & 28 & Male & $2016 \& 2017$ & Thailand & - & - \\
\hline P6 & 61 & Female & $2014 \& 2015$ & Thailand & Over the next 1 year & Thailand \\
\hline P7 & 19 & Female & 2016 & Thailand & - & - \\
\hline P8 & 29 & Female & 2015 & Thailand & - & - \\
\hline P9 & 57 & Female & 2015 & Thailand & - & - \\
\hline P10 & 57 & Female & 2017 & Indonesia & - & - \\
\hline
\end{tabular}




$\begin{array}{lcccccc}\text { P11 } & 35 & \text { Female } & 2016 & \text { Indonesia } & - & - \\ \text { P12 } & 21 & \text { Female } & 2016 & \text { Thailand } & - & - \\ \text { P13 } & 49 & \text { Female } & 2014 & \text { Thailand } & - & - \\ \text { P14 } & 26 & \text { Male } & 2017 & \text { Indonesia } & - & - \\ \text { P15 } & 20 & \text { Male } & 2016 & \text { Indonesia } & \text { Over the next 1 year } & \text { Indonesia } \\ \text { P16 } & 21 & \text { Female } & - & - & \end{array}$

243 The second stage involved a self-administrated online survey. A total of 51 Australians

244 travellers who had travelled to Indonesia, Thailand or Vietnam in the preceding three years 245 were invited to pilot test the online survey. After improving and revising the formal survey, it 246 was distributed among the online panel and a total of 279 completed survey responses were 247 included for the subsequent quantitative analyses. The panel consists of Australian travellers 248 who had also been to Indonesia, Thailand, and Vietnam in the preceding three years.

249 Approximate half the respondents were female (50.2\%) and male (49.8\%). The average age 250 was 44 years, and half were married (50.5\%). A total of $49.1 \%$ of respondents had completed 251 either a Bachelor or Postgraduate degree as their highest qualification, while $31.9 \%$ of them 252 completed a certificate or diploma from TAFE; 19\% of them completed Year 12 or below. The 253 respondents were asked to indicate how many children they have with $39.4 \%$ being childless. 254 The main reason for participants' latest trip to Indonesia, Thailand or Vietnam was for holiday 255 or leisure $(83.5 \%)$, to visit friends or relatives (11.1\%), for business $(3.2 \%)$, and others $(2.2 \%)$. 256 Our chosen sample was thus those holidaying (80.1\% for holiday), which fits with Australia's 257 National Visitor Survey Outbound Trips Results (Tourism Research Australia, 2016) showing 258 that such leisure was the main purpose of these trips to these three countries.

\subsection{Measurement of PMT constructs}

260 The measurement scales were developed using the literature and interview results. To measure 261 perceived vulnerability, the respondents were asked to rate the likelihood of experiencing 262 rabies while travelling to Indonesia, Thailand and Vietnam using a 5-point Likert-type scale 263 (1= extremely unlikely, 5= extremely likely) adapted from Sharifpour et al. (2014).

264 To measure perceived severity, participants were asked to rate how severe they think the 265 consequences of rabies may be while travelling to Indonesia, Thailand and Vietnam on a 5266 point Likert scale ( $1=$ not at all serious, 5= extremely serious) (Martin, Bender, \& Raish, 2007).

267 To measure actual self-protective behaviors, the participants were asked to indicate if they 268 have undertaken any risk reduction behaviors using a binomial scale ( $1=$ yes, $2=$ No), and the 
269 list of risk reduction behaviors (e.g., GP, vaccinations, travel insurance) that were extracted

270 from the findings of interviews.

271 To measure self-efficacy, the respondents were asked to evaluate their confidence in protecting 272 themselves against rabies during their travel to Indonesia, Thailand and Vietnam $(1=$ not 273 confident at all, 5= absolutely confident) (Rimal \& Real, 2003).

274 To measure response efficacy, the participants were asked to evaluate the efficacy of how they 275 protect themselves against risk (e.g., GP, vaccinations, travel insurance) (1= not effective at all, $2765=$ extremely effective) (Martin et al., 2007).

277 To measure intentions to perform protective behaviors, the respondents were asked to rate the 278 extent to which they agreed with behaving to protect themselves if they are taking a trip to 279 Indonesia, Thailand and Vietnam in the next 6 months ( $1=$ strongly disagree, $5=$ strongly agree).

280 To measure rewards from behaving to self-protect, the participants were asked to indicate the 281 extent to which they agreed with the list of benefits of protections against rabies ( $1=$ strongly 282 disagree, $5=$ strongly agree) (Floyd et al., 2000).

283 To measure costs, the participants were asked to indicate the extent to which they agreed with 284 the list of disadvantages of protecting themselves against rabies $(1=$ strongly disagree, $5=$ 285 strongly agree) (Floyd et al., 2000).

286 To measure maladaptive perception, six statements were developed based on interview results 287 and the literature (Rippetoe \& Rogers, 1987; Tanner et al., 1991). The respondents were asked 288 to rate the extent to which they agreed with the six statements representing different types of 289 maladaptive perceptions, namely, holiday spirit, avoidance, denial, wishful thinking, religious 290 faith, and fatalism, on a 5-point Likert scale ( $1=$ strongly disagree, 5= strongly agree).

RESULTS AND DISCUSSION

\subsection{Interview results}

293 Interview questions were related mainly to travel health perceptions and final or planned 294 behaviors of participants who have travelled to the three Southeast Asian countries in the last 295 three years or intended to do so in the next three. Findings of the interview data show that the measurement scales of the PMT constructs need to be modified. More specifically, three main 
297 protective behaviors were identified, namely, 'consulting health professionals (e.g., local or 298 family doctor)', 'obtaining recommended vaccinations prior to travel', and 'taking out travel insurance covering me for the trip'. This finding agrees with a study finding that travel insurance and vaccinations are among the top risk reduction strategies for travellers when touring the East context (Lo et al., 2011). The interview also ascertained the advantages and disadvantages of each health risk reduction strategy, and thus used them as survey items within the quantitative phase of this study.

304 The interview results also told us about maladaptive responses, a concept that has been omitted from tourism research. Our results also showed that individuals chose not to engage in any selfprotective behaviors because they have overcome similar risky situations in the past without taking any actions (Tanner et al., 1991). In the interview, participants indicated that 'past experience', and 'confidence in their health' are the main reasons why travellers were not concerned with their health. In contract to the health literature, this study found that "holiday spirit" emerged as a central theme of respondents' interpretation of maladaptive responses. For example, one participant mentioned, "maybe because of my holiday spirit, I just want to have

312 fun when travelling and do not want to concern any health issues". This is unique to tourism 313 while at the same time, highlights the importance of expanding the application of PMT.

\section{$314 \quad 4.2$ Model Testing Results}

\subsubsection{Principal component analysis (PCA) of the PMT constructs}

316 An important step to ensure the suitability of PMT to our research involving its scale reliability. 317 Measuring the PMT constructs in this study are based on both the literature and interview 318 results (e.g., six items for 'perceived rewards', seven items for 'perceived costs'). It is 319 important to reduce a large set of variables so that it still contains most of the information 320 (Yong \& Pearce, 2013). Thus, we conducted principal component analysis to assess how 321 suitable the conceptual model was for this study. Six constructs occupy the current study: 322 vulnerability to rabies disease, severity of experiencing rabies, self-efficacy of taking protective 323 actions, response efficacy of protective actions, costs, and rewards of taking actions (See Table 324 3). The results of the PCA test led us to drop an item: "Pre-departure rabies vaccine course is 325 only necessary once, then I am covered for future trips also" from the Rewards construct. The 326 revised scale appears to be reliable as the part-whole correlation and $\mathrm{R}^{2}$ values of all items were 327 greater than 0.4 and the Cronbach's $\alpha$ values were greater than .7 (Leech, Barrett, \& Morgan, 
328 2005). For constructs that include several items, the mean value was computed to develop

330 Table 3: Principal component analysis of PMT constructs and means of composite variables

\begin{tabular}{|c|c|c|c|c|c|c|}
\hline PMT constructs and items & Mean & SD & Loading & $\begin{array}{l}\text { Eigen } \\
\text { value }\end{array}$ & $\begin{array}{c}\text { \% of } \\
\text { Variance }\end{array}$ & $\begin{array}{c}\text { Reliability } \\
\alpha\end{array}$ \\
\hline Construct \#1: Vulnerability (1 item) & 2.50 & 1.021 & & & & \\
\hline Construct \#2: Severity (1 item) & 3.93 & .917 & & & & \\
\hline Construct \#3: Self-efficacy (3 item) & 3.95 & .765 & - & 2.141 & 71.354 & .799 \\
\hline $\begin{array}{l}\text { Consulting regular health professionals (local GP/family } \\
\text { doctor) }\end{array}$ & 3.87 & .957 & .864 & & & \\
\hline Obtaining recommended vaccinations prior to travel & 3.92 & .904 & .858 & & & \\
\hline Taking out travel insurance covering me for the trip & 4.05 & .853 & .812 & & & \\
\hline \multicolumn{7}{|c|}{ Kaiser-Meyer-Olkin Measure of Sampling Adequacy $=.701$, Bartlett's test of Sphericity: $\chi^{2}=262.439, p<.000$} \\
\hline Construct \#4: Response-efficacy & 3.91 & .770 & - & 2.080 & 69.348 & .779 \\
\hline $\begin{array}{l}\text { Consulting regular health professionals (local GP/family } \\
\text { doctor) }\end{array}$ & 3.76 & .928 & .830 & & & \\
\hline Obtaining recommended vaccinations prior to travel & 3.99 & .952 & .837 & & & \\
\hline Taking out travel insurance covering me for the trip & 3.98 & .893 & .831 & & & \\
\hline \multicolumn{7}{|c|}{ Kaiser-Meyer-Olkin Measure of Sampling Adequacy $=.703$, Bartlett's test of Sphericity: $\chi^{2}=226.945, p<.000$} \\
\hline Construct \#5: Costs (7 items) & 3.19 & .680 & - & 3.478 & 49.684 & .825 \\
\hline Obtaining rabies vaccination is expensive & 3.24 & .947 & .754 & & & \\
\hline $\begin{array}{l}\text { Obtaining pre-exposure rabies vaccine (multiple intake) is } \\
\text { time consuming. }\end{array}$ & 3.14 & .926 & .788 & & & \\
\hline Receiving the rabies vaccine may cause side effects & 3.37 & .866 & .706 & & & \\
\hline $\begin{array}{l}\text { If I don't get bitten by an animal with rabies, the pre- } \\
\text { exposure vaccine will have been a waste of money }\end{array}$ & 2.85 & 1.091 & .683 & & & \\
\hline $\begin{array}{l}\text { GP service only provides generic health consultations, not } \\
\text { specific for travel-related health consultation. }\end{array}$ & 3.08 & .969 & .729 & & & \\
\hline Not all GP clinics have rabies vaccination & 3.46 & .863 & .658 & & & \\
\hline Travel insurance only covers the money, does not protect & 3.17 & 1.128 & .599 & & & \\
\hline
\end{tabular}

Kaiser-Meyer-Olkin Measure of Sampling Adequacy $=.853$, Bartlett's test of Sphericity: $\chi^{2}=612.988, \mathrm{p}<.000$

\begin{tabular}{|c|c|c|c|c|c|c|}
\hline Construct \#6: Perceived Rewards (5 items) & 3.82 & .689 & - & 2.876 & 57.341 & .807 \\
\hline $\begin{array}{l}\text { Pre-departure rabies vaccine gives peace of mind in the } \\
\text { event of a rabies risk exposure. }\end{array}$ & 3.88 & .909 & .836 & & & \\
\hline $\begin{array}{l}\text { Obtaining rabies vaccine can save money for medical } \\
\text { treatment in case I am bitten by animals. }\end{array}$ & 3.80 & .923 & .788 & & & \\
\hline $\begin{array}{l}\text { Consulting GP can increase my knowledge of the travel } \\
\text { related risks including rabies. }\end{array}$ & 3.87 & .899 & .719 & & & \\
\hline $\begin{array}{l}\text { Consulting GP is bulk billed so there is no out of pocket } \\
\text { costs }\end{array}$ & 3.67 & 1.007 & 610 & & & \\
\hline Travel insurance can cover costs in case I am bitten by & 3.89 & .840 & .710 & & & \\
\hline \multicolumn{7}{|c|}{ Kaiser-Meyer-Olkin Measure of Sampling Adequacy $=.802$, Bartlett's test of Sphericity: $\chi^{2}=467.454, p<.000$} \\
\hline MV: Intentions to take protective actions & 3.83 & .862 & - & 2.104 & 70.123 & .786 \\
\hline Consult GP & 3.65 & 1.028 & .862 & & & \\
\hline Take vaccinations prior to travel & 3.77 & 1.057 & .871 & & & \\
\hline Take insurance covering me for the trip & 4.06 & 1.002 & .776 & & & \\
\hline \multicolumn{7}{|c|}{ Kaiser-Meyer-Olkin Measure of Sampling Adequacy $=.679$, Bartlett's test of Sphericity: $\chi^{2}=254.922, p<.000$} \\
\hline DV: Actual Protective Behaviors (Yes/No)* & & & - & 1.591 & 53.046 & \\
\hline Consulting GP & \multirow{3}{*}{\multicolumn{2}{|c|}{$\begin{array}{l}41 \%(115 / 279) \\
34 \%(95 / 279) \\
43 \%(120 / 279)\end{array}$}} & .719 & & & \\
\hline Take vaccinations prior to travel & & & .757 & & & \\
\hline Take insurance covering me for the trip & & & .708 & & & \\
\hline
\end{tabular}


Kaiser-Meyer-Olkin Measure of Sampling Adequacy $=.622$, Bartlett's test of Sphericity: $\chi^{2}=66.126, p<.000$

* There are 61 participates did nothing.

\subsubsection{Principal component analysis (PCA) of the maladaptive perceptions}

332 Maladaptive response is another important construct in PMT and is one of the coping modes.

333 PCA was conducted to explore the underlying dimensions (see Table 4), which shows that only

334 two components were extracted, the first was titled 'internal locus of control', which concerns

335 mainly travellers and covers statements about holiday spirit, avoidance, and wishful thinking;

336 the second component was titled 'external locus of control', which deals with external

337 influences and covers statements about religious faith and fatalism. Regarding maladaptive

338 perceptions, the participants scored relatively higher on items related to internal locus of

339 control.

340 Table 4: Principal component analysis of maladaptive perceptions

\begin{tabular}{|c|c|c|c|c|c|c|}
\hline & Mean & SD & Loading & $\begin{array}{l}\text { Eigen } \\
\text { value }\end{array}$ & $\begin{array}{c}\text { \% of } \\
\text { Variance } \\
\end{array}$ & $\begin{array}{c}\text { Reliability } \\
\alpha\end{array}$ \\
\hline Maladaptive perceptions* & 2.75 & .827 & & & & .829 \\
\hline Component 1-internal locus of control & 3.00 & .851 & & 1.881 & 31.355 & .733 \\
\hline $\begin{array}{l}\text { - I try not to think too much about health risks } \\
\text { every time I travel, and the trip to Thailand/ } \\
\text { Indonesia/ Vietnam is no exception. }\end{array}$ & 2.99 & 1.124 & .795 & & & \\
\hline $\begin{array}{l}\text { - I won't feed, pat or play with animals so don't } \\
\text { have to worry about rabies. }\end{array}$ & 3.19 & 1.027 & .826 & & & \\
\hline $\begin{array}{l}\text { - I have always been healthy and have a strong } \\
\text { immune system, so will be fine for rabies when I } \\
\text { travel to Indonesia or Thailand. }\end{array}$ & 2.82 & 1.008 & .667 & & & \\
\hline Component 2-external locus of control & 2.49 & 1.054 & & 2.514 & 41.900 & .858 \\
\hline $\begin{array}{l}\text { - I believe a miracle cure will occur in the future } \\
\text { for any health issues I may encounter during my } \\
\text { trips to Indonesia or Thailand. }\end{array}$ & 2.46 & 1.124 & .833 & & & \\
\hline - God will protect me from any potential harm. & 2.42 & 1.250 & .903 & & & \\
\hline - If you are destined to die from health incidents & 2.59 & 1.204 & .835 & & & \\
\hline
\end{tabular}
during your trip, you will; there is really very little you can do about it.

Kaiser-Meyer-Olkin Measure of Sampling Adequacy $=.781$, Bartlett's test of Sphericity: $\chi^{2}=715.195, p<.000$

$341 *$ Developed based on interview results and literature, $1=$ strongly disagree... 5= strongly agree

342 The results suggest that the most common type of maladaptive perceptions among the

343 participants is avoidance. This is consistent with an earlier study, which reveals that avoidant

344 thinking can reduce people's fear of threats and even further weaken their intentions to adopt

345 risk reduction strategies (Rippetoe \& Rogers, 1987). When it comes to our research, nearly half 
$346(40.2 \%)$ of the participants believed that they can avoid being exposed to wild animal contacts

347 (e.g., do not feed, pat or play with animals) during their trips, and thus, there is no need to 348 worry about rabies. Another common type of maladaptive perceptions among the participants 349 involves the good feelings about holidays (also called the holiday spirit). Our results suggest 350 that more than one-third (38.7\%) of participants try not to think about health risks while 351 travelling. This is unique to tourism and travel because escape and hedonism commonly 352 motivate travel as indicated by two specific behaviors of travellers: first, they tend to emphasize

353 the fun and benefits of travel while intentionally ignoring various health risks; and second, they 354 can sometimes be seen as an at-risk population being normally unfamiliar with the environment 355 of their destination and know little about what resources are available to protect themselves. 356 Rabies risk does not 'take a holiday' despite their maladaptive perceptions potentially leading 357 to their lack of self-protective behaviors. This finding also stresses the importance of 358 understanding maladaptive perceptions in travel and tourism.

\subsection{Model testing}

360 Following previous application of PMT (Yan et al., 2014; Yarmohammadi, Sharifabad, \& 361 Rahaei, 2014), four perceptions items were developed from the six PMT constructs: (1) 362 perceived threat of rabies risks, whose score is calculated according to vulnerability and 363 severity items; (2) perceived efficacy of taking protective actions, whose score is calculated 364 using self-efficacy and response efficacy; (3) perceived cost, and (4) perceived rewards of 365 taking protections. Two PMT pathway scores were computed. The threat appraisal score $=$ 366 perceived rewards scores minus the perceived threat score. The coping appraisal scores $=$ the 367 perceived efficacy score minus perceived cost score (Yan et al., 2014). Pearson correlations 368 were calculated to demonstrate the relationships among major constructs (See Figure 2).

369 The conceptual model was tested by a series of regression analyses using SPSS 25. The two 370 PMT pathways (threat-and coping-appraisal) and maladaptive perceptions were entered as 371 the independent variables; the protective intention was treated as the mediating variable, and 372 the protective behavior was treated as the dependent variable. The results are reported in Figure

3732 . The full model was statistically significant $\left(\chi^{2}(\mathrm{df}=4, N=279)=37.254, p<.01\right)$, and explain 374 between $12.5 \%\left(\right.$ Cox \& Snell $\left.\mathrm{R}^{2}=.125\right)$ to $17.4 \%\left(\right.$ Nagelkerke $\left.\mathrm{R}^{2}=.174\right)$ of the variance in the 375 response behavior. The protective intentions determine the likelihood of travellers' engaging 376 in actual protective behaviors $(\beta=.955, \mathrm{df}=1, p<.01)$, and explain $26.6 \%$ of the variance $377\left(\mathrm{R}^{2}=.266, \mathrm{~F}(\mathrm{df}=3, N=279)=33.276, p<.01\right)$. Both the threat appraisals $(\beta=.135, p<.05)$ 
and coping appraisals $(\beta=.478, p<.01)$ significantly influence protective intentions. The results provide support to $\mathrm{H} 1, \mathrm{H} 3, \mathrm{H} 7, \mathrm{H} 8$, and $\mathrm{H} 9$, but did not support $\mathrm{H} 2, \mathrm{H} 4, \mathrm{H} 5, \mathrm{H} 6$ and H10.

Figure 2: Full PMT Model Testing Results

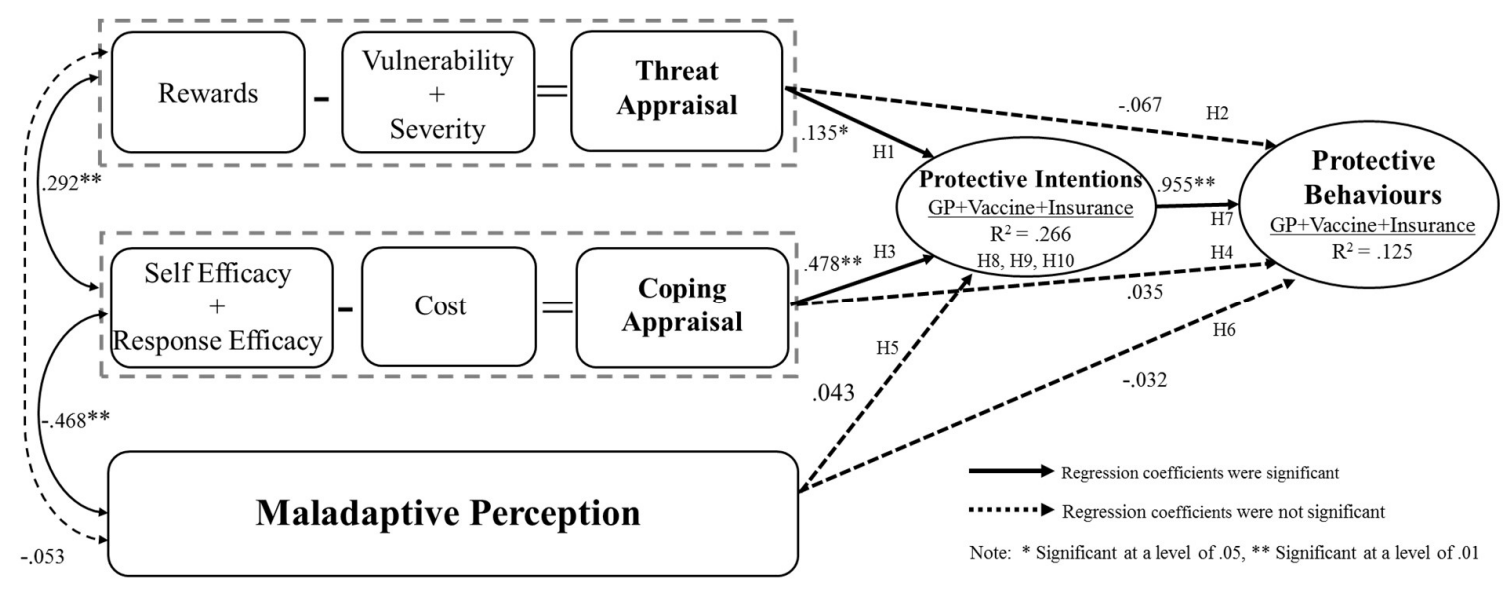

(Note: Key findings. H1) Both threat- and coping appraisal significantly predict intentions. H7) Behavioral intentions significantly predict behaviors. H8 \& H9) Intentions mediate the relationships between cognitive appraisals and actions. Additionally, maladaptive perception is negatively associated with coping appraisal.)

Our primary objective was to assess the utility of adapting PMT and applying it to explain travel health risks. The results support this application of the PMT to a tourism and travel context, which contributes theoretically in two ways. First, the results support the main PMT assumptions, that both threat and coping appraisal can influence individuals' intentions to protect themselves. For example, Fisher et al. (2018) examine cruise passengers' handwashing intentions and find that only the constructs related to the coping appraisal (e.g., responseefficacy, self-efficacy, and cost) predict protective intentions. However, the threat appraisal related constructs (severity and susceptibility) did not play a role in the decisions-making process. The findings of our study showed that both PMT appraisal determined individuals' intentions to protective themselves. This may be partly because our study includes the construct reward, which is consistent with the PMT model but neglected in Fisher et al's research. Furthermore, this study notes that, compared to the threat appraisal, the coping appraisal more strongly affected the outcome variable. This finding aligns well with other PMT studies in public health, which address a higher predictive power assumed by the coping appraisal (Floyd et al., 2000; Milne et al., 2000). Given the support to our hypotheses, future studies could use PMT to explore different topics and enrich the body of literature. 
402 Second, compared to other variables, this study notes that behavioral intentions do possess the 403 strongest predictive power of the participants' actions although the effect size remains 404 relatively small. Thus, future studies could concentrate on people's behavior rather than simply 405 testing their intentions. We also recommend using other models to explore similar topics 406 related to health risks at travel. Options such as the health belief model could be to explore 407 individuals' health and self-protective behavior while travelling.

408 Third, the findings support the mediation hypotheses (H8, H9) suggesting that the relationship 409 between appraisals and the action largely depends on protective intentions. Instead of simply 410 measuring the relationships between constructs, this finding furthers our understanding of

411 travellers' health behaviors by clearly demonstrating how the constructs are related and in what 412 way they influence people's protection. Revealing the underling relations is one of the major 413 findings of this study.

414 Finally, yet importantly, this study includes maladaptive perception in the full PMT model 415 testing. The results showed that this construct is neither associated with the participants' 416 intentions nor their actual behaviors. However, the results of the Pearson correlation tests 417 showed that maladaptive perception is negatively associated with the coping appraisal. This is 418 consistent with the original PMT assumptions and some literature (Fardell et al., 2016; 419 Rippetoe \& Rogers, 1987), which suggest that, when exposed to a high-risk situation, 420 individuals may be influenced by maladaptive perceptions and fail to engage in preventive 421 actions. Thus, even though maladaptive perception may not determine one's behavioral 422 intentions, it is likely that it may still play an important role in determining the engagement of 423 different appraisal modes. Built on these findings, future studies can explore if there exists a 424 specific chain of order of the decision-making process (Floyd et al., 2000).

\section{CONCLUSION AND IMPLICATIONS}

426 Health, safety, and well-being are important topics in tourism studies. This study applied the 427 Protection Motivation Theory (PMT) to explore travellers' self-protective behaviors against 428 health risk. This study combines the fields of public health and tourism management to 429 encourage travellers to engage in self-protective behavior against health risks. The findings of 430 this study explain how to ensure individuals' health and safety while at travel, which can greatly 431 contribute to their overall well-being. 
433 From a theoretical perspective, our study marks an early attempt in tourism studies to expand 434 and test the PMT model fully. Firstly, this study confirms the hypotheses by concluding that 435 both the threat and coping appraisal can encourage travellers to protect themselves, and behave 436 accordingly while travelling. The findings not only emphasize the significance of 437 understanding individuals' risk planning and reducing behaviours, but also indicate the 438 importance of turning intentions into actions. Furthermore, our findings provide new 439 perspectives about the construct of 'maladaptive response', which has been mentioned in the 440 PMT literature but has never been tested in tourism and travel research. We find that both 441 avoidance and holiday spirit are the most common types of travellers' maladaptive perceptions 442 in our study. Although they did not directly determine people's behaviors, they are negatively 443 associated with coping appraisal and may influence decision making. Additionally, the findings 444 of the factor analysis suggest that maladaptive perceptions can be further divided into two types, 445 both of which differed in the locus of control. This meaningful notion is useful for our research 446 and for future studies exploring other travel health issues.

447 Regarding tourism, our findings further the understanding of tourists' health behaviors. Instead 448 of simply using PMT to explain tourists' tendency to avoid risky situations and decisions, we 449 tested the full PMT model and were able to demonstrate how tourists' perceptions and thoughts 450 may affect their intentions and behaviors. While the major findings were consistent with the 451 PMT, this study did provide new perspectives about the construct of maladaptive perceptions 452 by highlighting the new dimension of holiday spirit and the new perspective involving the locus 453 of control. The findings show the popular preventive measures against health risks among 454 international tourists.

455 Moving beyond tourism, the major contribution of this study lies in theory testing (De Vaus, 456 2001). Using deductive reasoning derived from PMT and related literature, this study 457 developed and tested ten hypotheses. Although the results supported five of the hypotheses, it 458 is noted that maladaptive perceptions did not directly affect the participants' intentions or 459 behaviors. Because this is unexpected, it deserves further attention to explore the underlying 460 reasons. Additionally, this study attempted to explain "why" tourists adopt protective behaviors 461 against health risks by using the PMT model to explain. According to Whetten (1989) and De 462 Vaus (2001), this is one of the most challenging yet essential steps in theory building; in 
463 achieving this, we believe that this study has contributed to social science by exploring travel 464 health risks from a social psychology perspective.

\section{$465 \quad 5.2$ Practical Implications}

466 This paper also has practical implications. Firstly, it contributes to the existing body of 467 knowledge on how to motivate travellers to engage in risk prevention and reduction behaviors. 468 Ensuring travellers' health and safety is obviously beneficial for them and thus assisting with 469 reaching this outcome is essential for both tourism researchers and practitioners and says that 470 practitioners need to make tourists' health and well-being their business.

471 Secondly, our findings suggest that more attention should be directed to the most influential 472 PMT pathway to achieve desired behavioral change. Given the stronger predictive power 473 assumed by the coping appraisal, future effort should be devoted to increase the perceived 474 efficacy (both self-efficacy and response efficacy) to encourage travellers to self-protect (Yan 475 et al., 2014). To do so, campaigns and communication strategies should specify such preventive 476 measures and ensure they are accessible to the tourist population.

477 Lastly, this study explored the construct, maladaptive perceptions in tourism and noted that 478 maladaptive perceptions are also related to travellers' sense of control. Also, avoiding wild 479 animal contacts has been communicated by officials as one of the major strategies against 480 rabies risk (as discussed earlier in Section 1.2). The reality, however, is different. Avoiding 481 animals is not enough: $40 \%$ of rabies risk exposures occur in travelers who were avoiding 482 contact with animals (Mills et al., 2011). Additionally, to obtain unique and memorable travel 483 experiences, international travellers are oftentimes encouraged to interact with wild animals in 484 popular tourist destinations. This is evident by a recent example where a traveller was reported 485 to face a life-threating situation after the monkey's bit him during his visit to Monkey Forest 486 in Bali (Cronshaw, 2016). The findings here are alarming in that (1) there are differences 487 between what people believe and how they behave; and (2) policy-makers and practitioners 488 need to come up with concrete, accurate, and practical risk reduction strategies to combat rabies.

489 When translated this into practical applications, it means that the most effective communication 490 strategy should centre around tourists. The goal is both to educate tourists and increase their 491 sense of control. Strong public education programs and media campaigns are needed to inform 492 the public and to change or correct potential misperceptions. In the long term, this can reduce 493 and even avoid the negative health consequences affecting international travel. 
494 LIMITATIONS AND FUTURE RESEARCH

495 This study carries several limitations that can offer opportunities for future research. First, the 496 data used in this study were collected from a self-reported online survey, which are confined 497 to people with access to internet. This may bias research findings. We used purposive sampling, 498 which although was important for this study, it may raise some concerns related to 499 generalizability and may challenge the external validity of the findings. In addition, although 500 this study only tested three risk reduction strategies that were identified from the interview 501 results; information-seeking is considered one of the most common risk-reduction strategies 502 for tourists (Lo et al., 2011). Thus, future studies could include this particular behavior or cover 503 a wider variety of risk reduction strategies. 
505

506

507

508

509

510

511

512

513

514

515

516

517

518

519

520

521

522

523

524

525

526

527

528

529

530

531

532

533

534

535

536

537

538

Atherton, T. C., \& Atherton, T. A. (1998). Tourism, travel and hospitality law. Sydney: LBC Information Services.

Australian Department of Foreign Affairs and Trade. (2018). Smartraveller travel advice: Indonesia. Retrieved from http://smartraveller.gov.au/countries/asia/southeast/pages/indonesia.aspx\#summary

Bockarjova, M., \& Steg, L. (2014). Can Protection Motivation Theory predict proenvironmental behavior? Explaining the adoption of electric vehicles in the Netherlands. Global environmental change, 28, 276-288.

Briggs, R., \& Habib, N. (2004). Healthy Travel: Effective Communication to Improve Travel Health Outcomes. Retrieved from London: https://www.nuffieldtrust.org.uk/research/healthy-travel-effective-communication-toimprove-travel-health-outcomes

Caruana, R., Crane, A., \& Fitchett, J. A. (2008). Paradoxes of consumer independence: A critical discourse analysis of the independent traveller. Marketing Theory, 8(3), 253272.

Chien, P. M., Sharifpour, M., Ritchie, B. W., \& Watson, B. (2016). Travelers' Health Risk Perceptions and Protective Behavior: A Psychological Approach. Journal of Travel Research, 56(6), 1-16. doi:10.1177/0047287516665479

Conner, M., \& Norman, P. (1996). Predicting health behavior. Search and practice with social cognition models. Appetite, 27(2), 135-150.

Conner, M., \& Norman, P. (2005). Predicting health behaviour : research and practice with social cognition models (2nd ed.). Maidenhead: Open University Press.

Cronshaw, D. (2016). NSW man faces rabies risk after monkey bites in Bali. The Sydney Morning Herald. Retrieved from https://www.smh.com.au/national/nsw/nsw-manfaces-rabies-risk-after-monkey-bites-in-bali-20160315-gnjbpd.html

Darbellay, F., \& Stock, M. (2012). Tourism as complex interdisciplinary research object. Annals of Tourism Research, 39(1), 441-458.

De Vaus, D. (2001). Research design in social research. London: SAGE.

Defranco, A., \& Morosan, C. (2017). Coping with the Risk of Internet Connectivity in Hotels: Perspectives from American Consumers Traveling Internationally. Tourism Management, 61, 380-393. doi:10.1016/j.tourman.2017.02.022

Fardell, J. E., Thewes, B., Turner, J., Gilchrist, J., Sharpe, L., Smith, A., . . B Butow, P. (2016). Fear of cancer recurrence: A theoretical review and novel cognitive processing formulation. Journal of Cancer Survivorship, 10, 663-673. 
Fisher, J. J., Almanza, B. A., Behnke, C., Nelson, D. C., \& Neal, J. (2018). Norovirus on cruise ships: Motivation for handwashing? International Journal of Hospitality Management, 75, 10-17. doi:10.1016/j.ijhm.2018.02.001

Floyd, D. L., Prentice-Dunn, S., \& Rogers, R. W. (2000). A meta-analysis of research on protection motivation theory. Journal of Applied Social Psychology, 30(2), 407-429. doi:10.1111/j.1559-1816.2000.tb02323

Frisby, E. (2003). Communicating in a crisis: The british tourist authority's responses to the foot-and-mouth outbreak and 11th September. Journal of Vacation Marketing, 9(1), 89-100.

Hampson, K., Coudeville, L., Lembo, T., Sambo, M., Kieffer, A., \& et al. (2015). Estimating the Global Burden of Endemic Canine Rabies. PLOS Neglected Tropical Diseases, 9(5), e0003709. doi:10.1371/journal.pntd.0003709

Henderson, J. C. (2004). Managing a health-related crisis: SARS in Singapore. Journal of Vacation Marketing, 10(1), 67-77.

Heywood, A. E., Watkins, R. E., Iamsirithaworn, S., Nilvarangkul, K., \& MacIntyre, C. R. (2012). A cross-sectional study of pre-travel health-seeking practices among travelers departing Sydney and Bangkok airports. BMC Public Health, 12(321), 1-9.

Horng, J.-S., Hu, M.-L. M., Teng, C.-C. C., \& Lin, L. (2014). Energy Saving and Carbon Reduction Behaviors in Tourism - A Perception Study of Asian Visitors from a Protection Motivation Theory Perspective. Asia Pacific Journal of Tourism Research, 19(6), 721-735. doi:10.1080/10941665.2013.797002

Jonas, A., Mansfeld, Y., Paz, S., \& Potasman, I. (2011). Determinants of health risk perception among low-risk-taking tourists traveling to developing countries. Journal of Travel Research, 50(1), 87-99.

Law, R. (2006). The Perceived Impact of Risks on Travel Decisions. International Journal of Tourism Research, 8, 289-300. doi:10.1002/jtr.576

Leech, N. L., Barrett, K. C., \& Morgan, G. A. (2005). SPSS for Intermediate Statistics: Use and Interpretation (2nd ed.). Mahwah, New Jersey: Lawrence Erlbaum Associates, Inc.

Liu, B., Kim, H., \& Pennington-Gray, L. (2015). Responding to the bed bug crisis in social media. International Journal of Hospitality Management, 47, 76-84. doi:10.1016/j.ijhm.2015.03.005

Lo, A. S., Cheung, C., \& Law, R. (2011). Hong Kong Residents' Adoption of Risk Reduction Strategies in Leisure Travel. Journal of Travel \& Tourism Marketing, 28(3), 240-260. doi:10.1080/10548408.2011.562851

Lu, S., \& Wei, J. (2018). Public's perceived overcrowding risk and their adoption of precautionary actions: a study of holiday travel in China. Journal of Risk Research, 121. doi:10.1080/13669877.2017.1422784 
602

603

604

605

606

607

608

609

610

611

612

613

Maddux, J. E., \& Rogers, R. W. (1983). Protection motivation and self-efficacy: A revised theory of fear appeals and attitude change. Journal of Experimental Social Psychology, 19(5), 469-479.

Marett, K., McNab, A. L., \& Harris, R. B. (2011). Social networking websites and posting personal information: An evaluation of protection motivation theory. AIS Transactions on Human-Computer Interaction, 3(3), 170-188.

Martin, I., Bender, H., \& Raish, C. (2007). What Motivates Individuals to Protect Themselves from Risks: The Case of Wildland Fires. Risk Analysis, 27(4), 887-900. doi:10.1111/j.1539-6924.2007.00930.x

Mills, D. J., Lau, C. L., \& Weinstein, P. (2011). Animal bites and rabies exposure in Australian travellers. Medical Journal of Australia, 195(11), 673-675. doi:10.5694/mja10.11413

Milne, S., Sheeran, P., \& Orbell, S. (2000). Prediction and intervention in health-related behavior: A meta-analytic review of protection motivation theory. Journal of Applied Social Psychology, 30(1), 106-143. doi:10.1111/j.1559-1816.2000.tb02308.x

Mitchell, V. W., Davies, F., \& Moutinho, L. (1999). Using neural networks to understand service risk in the holiday product. Journal of Business Research, 46(2), 167-180.

Novelli, M., Burgess, L. G., Jones, A., \& Ritchie, B. W. (2018). 'No Ebola...still doomed' The Ebola-induced tourism crisis. Annals of Tourism Research, 70, 76-87. doi:10.1016/j.annals.2018.03.006

Ourahmoune, N. (2016). Narrativity, temporality, and consumer-identity transformation through tourism. Journal of Business Research, 69(1), 255-263. doi:10.1016/j.jbusres.2015.07.038

Pechmann, C., Zhao, G., Goldberg, M. E., \& Reibling, E. T. (2003). What to convey in antismoking advertisements for adolescents: The use of protection motivation theory to identify effective message themes. Journal of Marketing, 67(2), 1-18. doi:10.1509/jmkg.67.2.1.18607

Piyaphanee, W., Kittitrakul, C., Lawpoolsri, S., Gautret, P., Kashino, W., Tangkanakul, W., .. . Tantawichien, T. (2012). Risk of Potentially Rabid Animal Exposure among Foreign Travelers in Southeast Asia. PLOS Neglected Tropical Diseases, 6(9), e1852. doi:10.1371/journal.pntd.0001852

Plotnikoff, R. C., \& Trinh, L. (2010). Protection motivation theory: is this a worthwhile theory for physical activity promotion? Exercise and sport sciences reviews, 38(2), 91-98.

Qi, C. X., Gibson, H. J., \& Zhang, J. J. (2009). Perceptions of Risk and Travel Intentions: The Case of China and the Beijing Olympic Games. Journal of Sport \& Tourism, 14(1), 4367. doi:10.1080/14775080902847439

Rack, J., Wichmann, O., Kamara, B., Günther, M., Cramer, J., Schönfeld, C., . . . FriedrichJänicke, B. (2005). Risk and spectrum of diseases in travelers to popular tourist destinations. Journal of Travel Medicine, 12(5), 248-253. 
614 Rainear, A. M., \& Christensen, J. L. (2017). Protection Motivation Theory as an Explanatory

615 Framework for Proenvironmental Behavioral Intentions. Communication Research 616 Reports, 34(3), 239-248.

617 Richter, L. K. (2003). International tourism and its global public health consequences. Journal 618 of Travel Research, 41(4), 340-347.

619 Rimal, R. N., \& Real, K. (2003). Perceived Risk and Efficacy Beliefs as Motivators of Change: 620 Use of the Risk Perception Attitude (RPA) Framework to Understand Health Behaviors. 621 Human Communication Research, 29(3), 370-399. doi:10.1111/j.14682958.2003.tb00844.x

Rippetoe, P. A., \& Rogers, R. W. (1987). Effects of components of protection-motivation theory on adaptive and maladaptive coping with a health threat. Journal of Personality and Social Psychology, 52(3), 596-604.

Rogers, R. W. (1975). A protection motivation theory of fear appeals and attitude change. Journal of Psychology, 91, 93-114.

Schroeder, A., Pennington-Gray, L., Donohoe, H., \& Kiousis, S. (2013). Using Social Media in Times of Crisis. Journal of Travel \& Tourism Marketing, 30(1-2), 126-143. doi:10.1080/10548408.2013.751271

Schroeder, A., Pennington-Gray, L., Kaplanidou, K., \& Zhan, F. (2013). Destination Risk Perceptions Among U.S. Residents for London as The Host City of the 2012 Summer Olympic Games. Tourism Management, 38, 107-119. doi:10.1016/j.tourman.2013.03.001

Sharifpour, M., Walters, G., Ritchie, B. W., \& Winter, C. (2014). Investigating the role of prior knowledge in tourist decision making: A structural equation model of risk perceptions and information search. Journal of Travel Research, 53(3), 307-322. doi: $10.1177 / 0047287513500390$

Slevitch, L., \& Sharma, A. (2008). Management of perceived risk in the context of destination choice. International Journal of Hospitality \& Tourism Administration, 9(1), 85-103.

Sönmez, S. F., \& Graefe, A. R. (1998). Determining future travel behavior from past travel experience and perceptions of risk and safety. Journal of Travel Research, 37(2), 171177.

Stacks, D., \& Michaelson, D. (2010). A Practitioner's Guide to Public Relations Research, Measurement and Evaluation: Business Expert Press.

Tanner, J. F., Hunt, J. B., \& Eppright, D. R. (1991). The protection motivation model: A normative model of fear appeals. The Journal of Marketing, 55(3), 36-45.

Tourism Research Australia. (2016). National Visitor Survey Results: Outbound trips. Retrieved from https://www.tra.gov.au/tra/2016/documents/nvs/NVS_Outbound YE Dec 2015.xlsx.

Tsaur, S.-H., Yen, C.-H., \& Chen, C.-L. (2010). Independent tourist knowledge and skills. Annals of Tourism Research, 37(4), 1035-1054. doi:10.1016/j.annals.2010.04.001 
653

654

655

656

657

658

659

660

661

662

663

664

665

666

667

668

669

670

671

672

673

674

675

676

677

678

679

680

681

682

683

UNWTO. (2017). Tourism Highlights. Retrieved from https://www.eunwto.org/doi/book/10.18111/9789284419029

Wang, W. C., Lin, C. H., Lu, W. B., \& Lee, S. H. (2018). When destination attractiveness shifts in response to climate change: tourists' adaptation intention in Taiwan's Kenting National Park. Current Issues in Tourism, 1-26. doi:10.1080/13683500.2018.1437715

Whetten, D. (1989). What Constitutes a Theoretical Contribution? The Academy of Management Review, 14(4), 490-495.

WHO. (2017). Health topics: Travel and health. World Health Organization Retrieved from http://www.who.int/topics/travel/en/.

Wilks, J., Stephen, J., \& Moore, F. (2013). Managing tourist health and safety in the new millennium (1st ed.). UK: Oxford: Routledge.

Wilson, P. J., \& Rohde, R. E. (2015). 8 things you may not know about rabies - but should. Elsevier Connect. Retrieved from https://www.elsevier.com/connect/8-things-youmay-not-know-about-rabies-but-should

World Health Organization [WHO]. (2018). International travel and health. Retrieved from https://www.who.int/ith/en/

Yan, Y., Jacques-Tiura, A. J., Chen, X., Xie, N., Chen, J., Yang, N., . . MacDonell, K. K. (2014). Application of the Protection Motivation Theory in Predicting Cigarette Smoking Among Adolescents in China. Addictive Behaviors, 39(1), 181-188. doi:10.1016/j.addbeh.2013.09.027

Yang, E. C. L., \& Nair, V. (2014). Tourism at Risk: A Review of Risk and Perceived Risk in Tourism. Asia-Pacific Journal of Innovation in Hospitality and Tourism, 3(2), 1-21. doi:10.7603/s40930-014-0013-z

Yarmohammadi, G. S. P., Sharifabad, M. A. M., \& Rahaei, Z. (2014). Determination of preventive behaviors for pandemic influenza $\mathrm{A} / \mathrm{H} 1 \mathrm{~N} 1$ based on protection motivation theory among female high school students in Isfahan, Iran. Journal of Education and Health Promotion, 3, 36-41.

Yong, A. G., \& Pearce, S. (2013). A Beginner's Guide to Factor Analysis: Focusing on Exploratory Factor Analysis. Tutorials in Quantitative Methods for Psychology, 9(2), 79-94. 